\title{
CRITICAL EVENT STUDIES: ISSUES AND PERSPECTIVES
}

\author{
MARTIN ROBERTSON, $* \dagger$ FAITH ONG, $\neq$ \\ LEONIE LOCKSTONE-BINNEY, $\ddagger$ AND JANE ALI-KNIGHT* \\ *The Business School, Edinburgh Napier University, Edinburgh, UK \\ †Honorary Fellow, Victoria University, Melbourne, Australia \\ $\ddagger$ William Angliss Institute, Melbourne, Australia
}

Introduction

The growth in number of events, their attendance, and associated media coverage have contributed to a corresponding groundswell of interest in event studies (Baum, Lockstone-Binney, \& Robertson, 2013). Since the mid-2000s, in part owing to Getz's (2007) seminal work in the area, event studies have been widely explored in research, beginning with a plethora of management-related studies and progressing beyond to conceptual and theoretical explorations (Lamond \& Platt, 2016; Page \& Connell, 2012; Thomas \& Bowdin, 2012). The popularity of event studies is unsurprising given the ubiquitous nature of events, with the general populace exposed to a myriad of organized events, ranging from small-scale, private celebrations to highly commercialized sport mega-events. The ubiquitous nature of events is greatly helped by their ability to make use of existing infrastructure, supplemented by the use of temporary structures designed and built especially. Often, events make use of public space and infrastrucutre, which makes adequate and effective event management imperative to the local community's acceptance of an event.
Stemming from this management focus is a preoccupation on events' instrumentality - that is, their ability to add value to allied sectors-instead of an examination of an events' intrinsic value (Baum et al., 2013; Getz, 2012). As a relatively young field in comparison to the disciplines it typically draws on for study, Baum et al. (2013) noted the lack of acceptance of events as a recognized field of study. This is an observation shared by other scholars (Lockstone-Binney \& Ong, 2019). Although early studies of planned events grew with impact assessments largely focusing on economic and financial gains (Kim, Boo, \& Kim, 2013), its scope gradually broadened to include other aspects of management, especially in the areas of attendee and experience management (Kim et al., 2013), and marketing and operations (K. Park \& Park, 2016). The temporal nature of events has not limited its scope of study; in fact, it has broadened to include other areas including event futures, trends, and forecasts (K. Park \& Park, 2016).

An area that has received unprecedented attention has been the study of sport and mega-events. As various media and technological advances encourage greater viewership of these large-scale events, their significance and impacts have come under greater 
scrutiny (Sant, Mason, \& Hinch, 2013). The shine of hosting such mega-events has worn off, leading to, as in the case of Oslo's bid to host the Winter Olympics, community objection to their cities' bids (Bender, 2017), which has in turn inspired greater exploration of event assessment to justify hosting such events. Event legacy, which is what an event leaves in its wake after the event itself has concluded, has also been the subject of enhanced debate (Leopkey \& Parent, 2017). Such studies have examined legacies from the perspective of legacy delivery outcomes, equal distribution of benefits in the host community, as well as the mechanisms and governance systems required for effective legacy generation (Lienhard \& Preuss, 2014; Lockstone-Binney, Holmes, Shipway, \& Smith, 2016; Parent \& Smith-Swan, 2013; Smith, 2014). Others have examined them from the perspective of volunteering (Lockstone-Binney et al., 2016), community inclusivity, and transferable skills (Holmes, Hughes, Mair, \& Carlsen, 2015), as well as environmental sustainability (Heck \& Terret, 2016).

The practicalities of event design and production have not been neglected in events research. As with other aspects of our lives, technologies in events have produced conveniences that enhance the experience of events through cocreation (Robertson, Yeoman, Smith, \& McMahon-Beattie, 2015). It is anticipated that technology will similarly promote a more immersive experience, with wearable devices, social media, and virtual reality enhancements designed to aid the delivery of personalized, enhanced experiences (Pasanen \& Konu, 2016; Robertson et al., 2015). This focus on practical skills has also been highlighted in research on event management education. Although higher education event management courses offer both practical and theoretical knowledge, the industry that employs event management graduates has often expressed preference for those who possess practical experience (Ryan, 2016). This preference has led event educators to incorporate industry contact and elements into their design of events management curriculum (Robertson, Junek, \& Lockstone-Binney, 2012).

Event management education, a field that is younger than its research counterpart, has generally taken on three key forms, stacked into a pyramidal hierarchy that indicates a cumulative consolidation of knowledge into exploration (Getz, 2007). At the most basic level, event design and production focus on the development of applied knowledge to provide students with skills that lead to well-executed events. At this basic level, knowledge is extensive and well documented, with myriad strategies to ensure good execution through design and production. This is closely related to the second area, that of event management, which builds on the event design and production knowledge with extensions into experience and cohesion, the community aspects of event management. Further building on these two forms is that of theoretical and conceptual discourses emanating from event studies knowledge, incorporating the triple bottom line of sustainability (social, economic, and environmental) into discussions of events.

Addressing Getz's (2012) call on event scholars to advance the field by assessing and interpreting literature from other fields and disciplines, there has been a steep rise in the growth of such eventrelated publications. At a journal level, there has been an increased number of event-focused journals, all of which have published an increasing number of articles at increasing frequency in recent years (K. Park \& Park, 2016). Furthermore, extending to journals in related fields of leisure, sport, and tourism, more event-related research has been published through these related outlets (K. Park \& Park, 2016). In total, the number of event publications rose from 150 in the years between 1998 and 2003 to 337 in the 5-year period starting 2008 (S. B. Park \& Park, 2017). Amid this burgeoning of events research, S. B. Park and Park (2017) found themes that dominated the research published between 1998 and 2013-namely those of destination, management, and marketing themes. These have usually involved discussion of the roles events play in destination marketing (Knott, Fyall, \& Jones., 2017; Sant et al., 2013; Werner, Dickson \& Hyde, 2016), providing memorable experiences (Beard \& Russ, 2017), and its impacts on destinations and venues (Michelini, Iasevoli, \& Theodoraki, 2017; Testa \& Metter, 2017). These articles continue the field's preoccupation on event instrumentality, while neglecting other aspects such as those of risk management (Harris, Jago, Allen, \& Huyskens, 2001), event failure (Getz, 2010; Getz \& Page, 2016; Harris et al., 2001), and the study of events at a macrolevel (Page \& Connell, 2012).

Despite the depth and breadth of existing events research, two key criticisms persist: the lack 
of theoretical standing and critical examination (Baum et al., 2013; Kim et al., 2013; LockstoneBinney \& Ong, 2019). Although there have been attempts to develop theories and assessment frameworks (Holmes \& Ali-Knight, 2017; Sadd, Fyall, \& Wardrop, 2017), these remain largely theoretical and empirically untested. There has also been strong criticism of the positivity that dominates event studies, especially as it relates to their instrumentality, without sufficient reflection and critical study (Rojek, 2014). The nascent rise of critical event studies (CES) is imperative to address Tribe's (2008) call to resist the positivist agenda by engaging in critical research to set an agenda for ethical management, governance, and coexistence with the wider external world. It is this area of event studies research that we focus on in this special issue.

\section{Critical Event Studies}

In considering critical event studies, a brief reference to critical pedagogy is made before an initial look at Critical Management Studies (CMS) prior to consideration of CES. As most students of education and teaching will know, Paul Freire's Critical Pedagogy (CP) (1973) stemmed from the body of Critical Theory, whose members sought to determine what they saw as a just society (Darder, 2014). By utilizing knowledge to ensure the autonomy of the mind and possible emancipation of the oppressed, the development of a student's critical capacity gave them the opportunity to transform their life. A banking model of education, where students receive knowledge in a predominantly passive way, on the other hand, served to oppress further (Darder, 2014).

Thus, it is interesting that it is observed that over the last two decades, CMS has been quiet and often tolerated rather than encouraged by management scholars (Dehler, 2009). King (2015) reflected that scholars have difficulty in applying CMS in management practice (whether as a volunteer or consultant) because of this resistance. Yet, academics have also been criticized for what Fournier and Grey (2000) describe as being self-referential (Alvesson, Bridgman, \& Willmott, 2009), dependent on their own sphere of knowledge and not venturing beyond it.

Further, CMS has been viewed in its educational application as a loose assembly of discourses
(Belhassen \& Caton, 2011) outside of conventional management education. This may explain why there is an emergent discussion of the failure of CMS to be practical (King \& Learmonth, 2015). Yet in a time of what is referred to as socioeconomic turbulence, there is also recognition of the need for critical management and critical management studies.

In a world foiled by social-economic turbulence, extreme movements towards political popularism, movements in global trade relations, global and national wealth polarization, a rise in concern about devastating changes in the natural environment, and a resounding growth in the voice against inequalities of — or determined by — gender or sex, management education must, it is argued, change (Anderson, Hibbert, Mason, \& Rivers, 2018). Could it - playing devil's advocate here-be surmised that in the UK, the 2017 Higher Education and Research Act has, as part of its purpose, a desire to determine new modes of academic engagement for that very purpose (Anderson et al., 2018)? Or is it, as Freire (1973) saw, a reaffirmation of a functionary and oppressive process? Or is this, itself, too simplistic?

We do indeed live in turbulent times (Shapiro \& Gross, 2013), but this turbulence and its affect can indicate a future of added value for CMS. There is much to infer that social, economic, and environmental changes will be a catalyst for an expansion of critical studies in the event management and event studies area(s). Similarly, Mezirow (1997) reflected on how dilemma and crisis-disorienting change-is likely to spark new forms of transformational thinking and learning. The transformation learning literature considers the need to change frames of reference in both our thinking and in the composition of answers that respond to problems or issues. For events and festivals, as an academic and research focus, and as a societal activity, transformation is no less significant and CES may be part of this transformative platform.

CES may be a timely response to counter decades of neoliberalist politicization of events and festivals, and divisive governance (Dredge \& Whitford, 2010, 2011; Whitford, Phi, \& Dredge, 2014). The recognition, analysis, and discourse found in critical event studies may also offer a way to move away from the neoliberalism focus of the event subject area. There are increasing numbers of the world's population turning against (or being turned against) a model 
that has been found to be wanting and that served its time. Lamond and Platt's (2016) edited text Critical Event Studies-Approaches to Research is an important collection of work from many researchers who may be part of that vital recording and, perhaps, offering considerations of change. So, too, Spracklen and Lamond's (2016) text Critical Event Studies offered a valuable record of the multivaried avenues in which the study of events can be found.

Although the significance of festivals and events and contestation is being mapped well, and has been for at least a decade, for example, place (Quinn, 2005; Waterman, 1998); identity (BrennanHorley, Connell, \& Gibson, 2007; Jeong \& Santos, 2004); meaning (Matheson, 2008; O’Callaghan \& Linehan, 2007); culture (Johnson, 2006; Waterman, 1998), and cultural capital (O’Callaghan \& Linehan, 2007), there are fewer views of what is beyond neoliberalism. Again, reference to the socioeconomic and sociopolitical turbulence of neoliberalism may explain this. It is determined by the here and now, by the very systems that much of the critical studies literature comment upon. Yet turbulence has not only an immediate effect, it has an effect further down the line-forward into the future. Accordingly, while much of the critical event studies literature indicates that it looks to determine pathways beyond the managerial or functional base in which event management is historically housed, it is unclear if it also refutes the future for being too simplistic or whether it feels the future can only be determined by the past and the now.

However, while it is true that the future is one element of critical event study that has received less thought, this does not mean it will continue do so. The chapters of the Spracklen and Lamond (2016) monographs offered eleven lenses into critical event studies. So, while there is an absence of overarching or strong unification, this may simply be evidence of what Fournier and Grey (2000) described as selfaffirmation and dependence on their own body of knowledge. As it grows this is likely to change.

\section{Lenses of Critical Event Studies in This Special Issue}

Adding to Lamond and Platt (2016) and Spracklen and Lamond's (2016) publications, this special issue was aimed at challenging the positivist agenda by examining events' role in relation to ethics, governance, and the wider world. The articles included in this special issue challenge the status quo by ascribing meaning to events beyond the neoliberalism that governs the expansionist ambitions of many events.

The instrumentality of events continues to be examined in this critical context, particularly as they relate to rurality, social cohesion, and identities. Moving away from the typical metropolitan focus of event studies, Mair and Duffy adopt a case study approach to examine the ability of the Clunestown Book Festival in rural Victoria, Australia, to address community concerns. As a retiring urban population moves into rural regions in search of a quieter lifestyle, their entrance brings with them a diversity that can result in social tensions. Mair and Duffy explore the event in relation to its aims of economic renewal, social inclusion, and sustainability, focusing on its success in building three forms of social capital within its community-bonding, bridging, and linking. The positive outcomes of the Clunestown Book Festival benefit those within its organizing committee and attendees, and those not directly involved in the event. Continuing the focus on rurality, Beer's autoethnographic study reflects on his personal experience as an attendee at rural shows, focusing on the evolution of events from being rural-focused to commodifying rurality. He evaluates changes wrought by four decades of rural event attendance and criticizes the current state of rural events for forsaking their main identity and creating an experience where urban consumerism takes center stage while quintessentially country activities such as sheep shows are relegated to sideshows.

Sporting events explored in this special issue provide critique of the environments and contexts within which such events operate. In particular, sports mega-events are in the spotlight due to the large-scale impacts they have. Examining the Glasgow 2014 Commonwealth Games, Sharp and Finkel emphasize the consultative stakeholder approach taken by Glasgow City Council to achieve national and local aims for the event. By building legacy consultation process in at the bidding stage, Sharp and Finkel describe how the event allowed for greater consultation, and consequently, stronger implementation of longer-lasting legacy governance structures and flexibility in execution. 
This positive example is used to encourage other events to consult with their communities early so that the benefits of hosting such events last longer and have a broader reach. Widening the focus to sports mega-events in general, Kirby, Duignan, and McGillivray critique the potentially exclusionary structures of such events and how they limit small and medium local businesses to reap the benefits of increased attendance. They call into question the leveraging legacies left in the wake of such megaevents, especially as they continue to be used as justification by cities in their bids to host. Continuing the contextual focus on sports mega-events, Nichols, Benson, and Holmes critique the regulatory capitalism employed at the London 2012 Olympic and Paralympic Games, with specific focus on volunteer research. As an autoethnographic study, the research team reflected on their experience working with the main market research company and demonstrate the impacts resulting from this regulatory capitalism on public accountability, research access, and ethics. Their research serves as caution against unfettered neoliberalism in the age of mega-events, with myriad implications that have to be taken into consideration and balanced against the timely delivery of such complex events.

Contestations of identity are also explored in relation to events in this special issue. Kennell, Šuligoj, and Lesjak extend the geographical sphere of CES to former states of Yugoslavia, where the political and cultural narratives of their identities are shaped by commemorative events. In examining darkness beyond the concept of entertainment and leisure, Kennell et al. posit that the darkness of an event is proportional to the kind of memories they draw on and the contemporary political significance of the occasion for commemoration. Further to this, Ong and Goh also take on the issue of identity as expressed by events, providing an in-depth case study of Pink Dot, a pride event in Singapore. As a pride event that is exclusively attended only by its citizens, it resists commodification while functioning as a vehicle for social change that is at once expressive and restricted by the stringent laws it operates in. Events' ability to contest identities and physical space is also explored in Jarvis's article on the 2014 Cleveland/Akron Gay Games, an event that has leaves sociopolitical and sport legacies. As with Pink Dot, Jarvis describes the
Gay Games as an accelerator of social acceptance towards the LGBT community, challenging the heteronormativity that generally governs sports. This contestation of marginalization is also a key theme of Zigomo and Hull's research on the decolonization of art exhibitions in Zimbabwe through the democratizing power of cocreation. By positioning the professional event organizer's risk aversion and time efficiency as a form of neoliberal colonization, Zigomo and Hull encourage the use of participatory event design with artist input to resist this colonization.

Chen, Mason, and Misener provide a critical discourse analysis of the representation of Indigenous Canadians in the media coverage of two international Indigenous sport events held in Canada in 2017. With reference to suggested gaps in both assimilation policy and education in Canada, and the confines of the mainstream media platform there, Chen et al. comment on how the limited consideration of settler colonialism elsewhere may indicate a deficiency in management studies.

In the area of event management education, Werner, Wang, and Gray chart the development of a Sino-German double degree program to parallel Getz's (2012) pyramidal hierarchy, progressing from operational focus to critical discussions relating to events. This progression of an event studies program is further reinforced at the highest level of education. In this respect, Lockstone-Binney evaluates the contributions to knowledge led by doctoral theses in Australia to conclude that sociology remains the key focus of event studies at the highest level of study. Lockstone-Binney also identifies gaps in knowledge, with recommendations ranging from the study of health benefits of event participation to environmental and sustainability impacts of events. This latter point is emphasized by Harris and Schlenker, with their study on the environmental impacts of Australian public events as critical to the future of events. With direction from event organizers, the findings of Harris and Schlenker point to a move away from an overemphasis on financial gain with concessions made towards environmental sustainability in its place.

In their research note, Robertson, Hutton, and Brown consider that there has been an overemphasis on planned behaviorist approaches to crowd management at outdoor music festivals, and not enough 
on the real time design of attendee experience. Referring to ethnographic data captures at outdoor music festivals in Adelaide, Australia, Robertson et al. propose a new set of responsibilities for music festival directors in what they consider as being a new construct of transformative civic responsibility at a critical time of social-economic turbulence. Their work draws on positive psychology (Filep, Volic, \& Lee, 2015).

\section{Establishing Critical Event Methodologies}

Lamond and Platt (2016) provided a significant consideration of the wide variety of research approaches being used by international academics whose interests lie within the reach of this emerging events field. Their text presented case studies and discussed different methodological approaches applicable to research within critical event studies (CES) and reaffirmed the need for more innovative research approaches away from more pragmatic business orientated ones. Pernecky's (2016) review and guide to qualitative research considered that "it is inadequate to speak of one realism, empiricism, rationalism, and idealism univocally; rather, there is a multiplicity of perspectives, and these have evolved and spilled over into other territories to give rise to modified outlooks" (p. 3). The importance of establishing critical methodologies has long been debated in tourism and Tribe (2007) highlighted the development of critical theory and questions the existence of a "business of tourism" (p. 33) paradigm that could be hostile to other interpretivist approaches. Veal (1997) also noted how tourism research has been driven by the demands of business to a much greater extent than other disciplines. There are promising signs for criticality when introducing the idea of the Foucauldian notion of discourse, using the tourist gaze (Urry, 1990) and showing how it acts in tourism and events research to direct how we perceive reality. Tribe (2007) and Chambers (2007) also noted the move towards a more critical approach but this is far from being a major paradigmatic shift. Echoing the work of Lamond and Platt (2016), Phillimore and Goodson (2004) also stated that "the time has come for tourism researchers to be more self-critical and more adventurous" (p. 193), trying new techniques in the field and with research participants, as well as developing a more reflexive approach to their work. There is an evident need for future event studies research to involve both positivistic and interpretivist philosophical traditions using both qualitative and quantitative data and groups of researchers rather than just individuals. Within the articles presented in this special issue, we witness a myriad of event methodologies being used. It is useful to examine how far these methodologies are pushing boundaries and aiming to be critical in their approach.

Some articles present an inherently theoretical approach testing new frameworks and approaches to the analysis of secondary research. Wood, Jepson, and Stadler present a framework that focuses on participatory arts events where the making/doing of something achievable in an inclusive, creative, and accessible setting is not only a vital part of the experience but is also a catalyst for important social interactions that potentially improve well-being. The proposed framework guides research into the processes that occur to in experiencing a socially creative activity. In more fully understanding these processes, arts events can be better designed to maximize the benefits to those participating, thus enabling a contribution analysis approach (Mayne, 2008). Wood et al. discuss the use of a systematic review when constructing this conceptual article using secondary research to draw together key areas previously omitted from event management studies. This focus around the key themes of older demographics, wellness, and participation is befitting CES. Kirkby, Duignan, and McGillivrary also use desk-based review to identify and analyze the current state of the art on medium-sized business (MSB) impacts and their role and relationship to megasport event (MSE) bidding, planning, and delivery.

Mair and Duffy adopt a qualitative methodological approach for gaining an understanding of the role bridging and linking social capital played in their research. The study adopted a phenomenological approach, in order to explore the lived experience of those being interviewed (Szarycz, 2009). Schulendorf, Thomson, and Schlenker (2011) discussed how social capital arises out of opportunities for socializing using participant observation as well as in-depth interviews with community stakeholders to observe and have participants reflect upon the emotional and affective relations 
occurring between individuals. Content analysis of local and regional media coverage of the festival under study also provided further access to the broader community's perceptions and response to the event.

Two articles focus on mega-event research examining both the London 2012 Olympics and Glasgow'shosting of the 2014 Commonwealth Games. Mega-event research has tended to focus on economic impacts, using quantitative techniques such as economic modeling. The studies presented in this special issue deviate from this approach using methods such as autoethnography to record the personal story of one of the coauthors. In an autoethnography, the authors use their own experiences to reflect on deeper issues associated with the research context (Dashper, 2016). In this case the article is concerned with the power relations between the private companies awarded the contracts for the London Olympic Games and academic researchers studying the event as well as examining ethical event behavior. The personal narrative of the researcher's experiences from working with Nielsen raises issues with broader application to how academics can conduct research at megaevents. Qualitative methodological approaches also inform the Commonwealth Games case study. The research emphasizes the diverse range of stakeholders within a host city linked to the potential to create legacies. Creswell (2007) stated key informant interviewees are "gatekeepers," often deemed well-informed and are able to provide opportunities leading to new insights, drawing vital information from a variety of people who have relevant expertise and experience to gain key stakeholder insights into legacy planning for Glasgow as a host city.

Beer's personal analysis of rural community events also uses autoethnography as the research method citing its relevant consideration with the ideas of critical theory and post modernism. He draws on his own experiences to examine cultural experiences through the lens of logocentrism, a viewpoint developed by Jacques Derrida (Derrida, 1973). Autoethnography is considered an approach that has helped to facilitate much critical theory, particularly as an agent in disrupting the norms of research practice and representation, so is highly appropriate for CES (Jones, Adams, \& Ellis, 2016).
Other qualitative methods used in this special issue include case study analysis. Yin (2014) suggested that a case study methodology is appropriate for exploratory research such as contained in some of these articles, especially when the focus is "a contemporary phenomenon within some reallife context.” Creswell (2007) explained, a case study approach is appropriate when the "inquirer has clearly identifiable cases with boundaries and seeks to provide an in-depth understanding of the cases or comparison of several cases” (p. 74). Kennell, Šuligoj, and Lesjak's examination of commemorative events associated with conflicts in the countries of the former Yugoslavia uses a purposive sample (Lavrakas, 2008) and makes use of the concept of collective memory to understand the relationship between commemorative events and memory in postconflict societies specifically. This examination of socio and political impacts through the prism of collective memory contributes to the emerging field of critical events studies.

Qualitative approaches such as stakeholder and resident interviews are not unique but as in the case of Jarvis's work with the Gay Games in Cleveland/Akron, the originality lies with the area of research and the understanding of the potential legacies of the Games. This qualitative method was felt to better understand opinions, relationships, and connections attached to the event (Mackellar, 2013), of not only those more closely connected to the Games, such as stakeholders but also those citizens not associated with the event. In the pursuit of understanding, Chen, Mason, and Misener's application of Critical Discourse Analysis (CDA) to media coverage of two Indigenous sport events is informed by settler colonialism, supporting Fairclough's (2010) assertation that CDA should be informed by other social theories.

Harris and Schlenker's examination of event sustainability is one of the few articles that uses a standardized quantitative approach. Exploratory in nature, the work intended to both develop an appreciation of what currently constitutes best practice in an area of evolving concern to event owners and managers, and to raise matters that might be further explored through more focused studies. Their work with the Sustainable Events Alliance as one of the industry's lead body in this area is unique and adds to the depth and originality of findings. 


\section{Conclusion}

This special issue of Event Management is a celebration of event studies and its development. It is also a pause for thought about the extent of event studies as an area of critical study. We celebrate the work that is presented in this collection and anticipate that there will be more to come. The voices captured here are important, each offering a reflection on the stimulation of the environment on which they comment, review, or translate. The contributions offer clear evidence of a transition in event studies, rather than an overt transformation towards critical events studies.

Given the ubiquitous nature of organized events in modern society, their capacity to either determine, affect, or house new paths of research should not be a revelation. On the face of it, nor should the purpose, form, methodology, or methods that may be encompassed by event studies be a surprise. However, critical mass and confidence take time to form, and new works in event studies contribute to that transition, providing a base for a transformative change. Accordingly, this special issue is an important record of contributions towards critical change, that is, Critical Event Studies.

\section{References}

Alvesson, M., Bridgman, T., \& Willmott, H. (2009). Introduction. In M. Alvesson, T. Bridgman, \& H. Willmott (Eds.), The Oxford handbook of critical management studies (pp. 1-28). Oxford, UK: Oxford University Press.

Anderson, L., Hibbert, P., Mason, K., \& Rivers, C. (2018). Management education in turbulent times. Journal of Management Education, 42(4), 423-440. doi: 10.1177/ 1052562918779421

Baum, T., Lockstone-Binney, L., \& Robertson, M. (2013). Event studies: Finding fool's gold at the rainbow's end? International Journal of Event and Festival Management, 4(3), 179-185.

Beard, C., \& Russ, W. (2017). Event evaluation and design: Human experience mapping. Event Management, 21(3), 365-374.

Belhassen, Y., \& Caton, K. (2011). On the need for critical pedagogy in tourism education. Tourism Management, 32(6), 1389-1396. https://doi.org/10.1016/j.tourman. 2011.01.014

Bender, A. (2017). Paris And Los Angeles will score Summer Olympics 2024 and 2028. Retrieved from https:// www.forbes.com/sites/andrewbender/2017/06/12/parisand-los-angeles-will-score-summer-olympics-2024-and2028/\#3bbad77950a2
Brennan-Horley, C., Connell, J., \& Gibson, C. (2007). The Parkes Elvis Revival Festival: Economic development and contested place identities in rural Australia. Geographical Research, 45(1), 71-84.

Chambers, D. (2007). An agenda for cutting-edge research in tourism. In J. Tribe \& D. Airey (Eds.), Developments in tourism research (pp. 234-244). Oxford, UK: Elsevier.

Creswell, J. W. (2007). Qualitative enquiry and research design: Choosing among five approaches. Thousand Oaks, CA: Sage Publications.

Darder, A. (2014). Freire and education. Oxon, UK: Routledge.

Dashper, K. (2016). Strong, active women: (Re)doing rural femininity through equestrian sport and leisure. Ethnography, 17(3), 350-368.

Dehler, G. E. (2009). Prospects and possibilities of critical management education: Critical beings and a pedagogy of critical action. Management Learning, 40(1), 31-49. doi: 10.1177/1350507608099312

Derrida, J. (1973). "Speech and phenomena" and other essays on Husserl's theory of signs [Translated by D. B. Allison]. Evanston, IL: Northwestern University Press.

Dredge, D., \& Whitford, M. (2010). Policy for sustainable and responsible festivals and events: Institutionalisation of a new paradigm-a response. Journal of Policy Research in Tourism, Leisure and Events, 2(1), 1-13.

Dredge, D., \& Whitford, M. (2011). Event tourism governance and the public sphere. Journal of Sustainable Tourism, 19(4-5), 479-499. doi: 10.1080/09669582.2011.573074

Fairclough, N. (2010). Critical discourse analysis: The critical study of language. Harlow, UK: Longman.

Filep, S., Volic, I., \& Lee, I. S. (2015). On positive psychology of events. Event Management, 19(4), 495-507.

Fournier, V., \& Grey, C. (2000). At the critical moment: Conditions and prospects for critical management studies. Human relations, 53(1), 7-32.

Freire, P. (1973). Education for critical consciousness. New York, NY: Bloomsbury Publishing.

Getz, D. (2007). Event studies: Theory, research and policy for planned events. London, UK: Elsevier ButterworthHeinemann.

Getz, D. (2010). The nature and scope of festival studies. International Journal of Event Management Research, 5(1), 1-47.

Getz, D. (2012). Event Studies. Florence, Italy: Taylor and Francis.

Getz, D., \& Page, S. J. (2016). Event studies: Theory, research and policy for planned events. London, UK: Routledge.

Harris, R., Jago, L., Allen, J., \& Huyskens, M. (2001). Towards an Australian event research agenda: First steps. Event Management, 6(4), 213-221.

Heck, S., \& Terret, T. (2016). Nature conservation versus event organisation: “Madmen's Diagonals” on Reunion Island (1989-2014). Journal of Policy Research in Tourism, Leisure \& Events, 8(1), 18-32.

Holmes, K., \& Ali-Knight, J. (2017). The event and festival life cycle-developing a new model for a new context. 
International Journal of Contemporary Hospitality Management, 29(3), 986-1004.

Holmes, K., Hughes, M., Mair, J., \& Carlsen, J. (2015). Events and sustainability. Florence, Italy: Taylor and Francis.

Jeong, S., \& Santos, C. A. (2004). Cultural politics and contested place identity. Annals of Tourism Research, 31(3), 640-656.

Johnson, L. (2006). Valuing the arts: Theorising and realising cultural capital in an Australian City. Geographical Research, 44(3), 296-309.

Jones, H. J., Adams, T. E., \& Ellis, C. (2016). Coming to know autoethnography is more the method. In S. H. Jones, T. E. Adams, \& C. Ellis (Eds.), Handbook of autoethnography (pp. 17-48). Abingdon, UK: Routledge.

Kim, J., Boo, S., \& Kim, Y. (2013). Patterns and trends in event tourism study topics over 30 years. International Journal of Event and Festival Management, 4(1), 66-83.

King, D. (2015). The possibilities and perils of critical performativity: Learning from four case studies. Scandinavian Journal of Management, 31(2), 255-265. doi: 10.1016/j.scaman.2014.11.002

King, D., \& Learmonth, M. (2015). Can critical management studies ever be "practical?” A case study in engaged scholarship. Human Relations, 68(3), 353-375.

Knott, B., Fyall, A., \& Jones, I. (2017). Sport mega-events and nation branding: Unique characteristics of the 2010 FIFA World Cup, South Africa. International Journal of Contemporary Hospitality Management, 29(3), 900-923.

Lamond, I. R., \& Platt, L. (2016). Critical event studies: Approaches to research. London, UK: Palgrave Macmillan.

Lavrakas, P. J. (2008). Encyclopedia of survey research methods. London, UK: Sage Publications.

Leopkey, B., \& Parent, M. M. (2017). The governance of Olympic legacy: Process, actors and mechanisms. Leisure Studies, 36(3), 438-451.

Lienhard, P., \& Preuss, H. (2014). Legacy, sustainability and CSR at mega sport events: An analysis of the UEFA EURO 2008 in Switzerland. Wiesbaden, Germany: Springer Gabler.

Lockstone-Binney, L., Holmes, K., Shipway, R., \& Smith, K. (2016). Evaluating the volunteering infrastructure legacy of the Olympic Games: Sydney 2000 and London 2012. Lausanne, Switzerland: IOC.

Lockstone-Binney, L., \& Ong, F. (2019). Event studies: Progression and future in the field. In S. Beeton \& A. Morrison (Eds.), The study of food, tourism, hospitality and events: 21st-century approaches (pp. 37-46). Singapore: Springer Singapore.

Mackellar, J. (2013). Participant observation at events: Theory, practice and potential. International Journal of Event and Festival Management, 4(1), 56-65.

Matheson, C. M. (2008). Music, emotion and authenticity: A study of Celtic Music Festival consumers. Journal of Tourism \& Cultural Change, 6(1), 57-74. https://doi. org/10.1080/14766820802140448
Mayne, J. (2008). Contribution analysis: An approach to exploring cause and effect. ILAC Brief 16 p. 4. Retrieved from https://cgspace.cgiar.org/handle/10568/ $\underline{70124}$

Mezirow, J. (1997). Transformative learning: Theory to practice. New Directions for Adult and Continuing Education, 1997(74), 5-12.

Michelini, L., Iasevoli, G., \& Theodoraki, E. (2017). Event venue satisfaction and its impact on sponsorship outcomes. Event Management, 21(3), 319-331.

O’Callaghan, C., \& Linehan, D. (2007). Identity, politics and conflict in dockland development in Cork, Ireland: European Capital of Culture 2005. Cities, 24(4), 311-323.

Page, S. J., \& Connell, J. (2012). The Routledge handbook of events. Hoboken, NJ: Taylor and Francis.

Parent, M. M., \& Smith-Swan, S. (2013). Managing major sports events: Theory and practice. Abingdon: Routledge.

Park, K., \& Park, S. (2016). Topic trend of event management research. Event Management, 20(1), 109-115.

Park, S. B., \& Park, K. (2017). Thematic trends in event management research. International Journal of Contemporary Hospitality Management, 29(3), 848-861.

Pasanen, K., \& Konu, H. (2016). Use of social media for new service development by Finnish event and festival organizers. Event Management, 20(3), 313-325.

Pernecky, T. (2016). Epistemology and metaphysics for qualitative research. London, UK: Sage Publications.

Phillimore, J., \& Goodson, L. (2004). Qualitative research in tourism: Ontologies, epistemologies, methodologies. Oxon, UK: Routledge.

Quinn, B. (2005). Changing festival places: Insights from Galway. Social \& Cultural Geography, 6(2), 237-252.

Robertson, M., Junek, O., \& Lockstone-Binney, L. (2012). Is this for real? authentic learning for the challenging events environment. Journal of Teaching in Travel and Tourism, 12(3), 225-241.

Robertson, M., Yeoman, I., Smith, K. A., \& McMahonBeattie, U. (2015). Technology, society, and visioning the future of music festivals. Event Management, 19(4), 567-587.

Rojek, C. (2014). Global event management: A critique. Leisure Studies, 33(1), 32-47.

Ryan, W. G. (2016). How do you “do” Event Management Education (EME)? A case study of event management higher education awards. Event Management, 20(1), 69-80.

Sadd, D., Fyall, A., \& Wardrop, K. (2017). Evaluative event frameworks: A learning destination perspective. International Journal of Tourism Research, 19(3), 339-348.

Sant, S.-L., Mason, D. S., \& Hinch, T. D. (2013). Conceptualising Olympic tourism legacy: Destination marketing organisations and Vancouver 2010. Journal of Sport \& Tourism, 18(4), 287-312.

Schulenkorf, N., Thomson, A., \& Schlenker, K. (2011). Intercommunity sport events: Vehicles and catalysts for social capital in divided societies. Event Management, 15(2), 105-119.

Shapiro, J. P., \& Gross, S. J. (2013). Ethical educational leadership in turbulent times: (Re)solving moral dilemmas. Oxon, UK: Routledge. 
Smith, A. (2014). Leveraging sport mega-events: New model or convenient justification? Journal of Policy Research in Tourism, Leisure and Events, 6(1), 15-30.

Spracklen, K., \& Lamond, I. R. (2016). Critical event studies. Oxon, UK: Routledge.

Szarycz, G. S. (2009). Some issues in tourism research phenomenology: A commentary. Current Issues in Tourism, 12(1), 47-58.

Testa, M. R., \& Metter, M. (2017). Assessing economic impact as a means for event efficacy: A proposed model and case study. Event Management, 21(1), 61-70.

Thomas, R., \& Bowdin, G. (2012). Events management: State of the art. Selected papers from the Global Events Congress IV, Leeds, England, UK, July 14-16, 2010. Event Management, 16(2), 103-187.

Tribe, J. (2008). Tourism: A critical business. Journal of Travel Research, 46(3), 245-255.

Tribe, J. (2007). Critical tourism: Rules and resistance. In I. Ateljevic, N. Morgan, \& A. Pritchard (Eds.), The critical turn in tourism studies: Innovative tourism methodologies (pp. 29-39). Oxford, UK: Elsevier.

Urry, J. (1990). The tourist gaze. London, UK: Sage Publications.

Veal, A. J. (1997). Research methods for leisure and tourism: A practical guide (2nd ed.). London, UK: Financial Times Management.

Waterman, S. (1998). Carnivals for elites? The cultural politics of arts festivals. Progress in Human Geography, 22(1), 54-74. doi: 10.1191/030913298672233886

Werner, K., Dickson, G., \& Hyde, K. F. (2016). Mega-events and increased collaborative capacity of tourism destinations: The case of the 2011 Rugby World Cup. Journal of Destination Marketing \& Management, 5(3), 227-238.

Whitford, M., Phi, G. T., \& Dredge, D. (2014). Principles to practice: Indicators for measuring event governance performance. Event Management, 18(3), 387-403.

Yin, R. K. (2014). Case study research and applications: Design and methods. London, UK: Sage Publications. 